\title{
Malignant and Benign T Cells Constituting Cutaneous T-Cell Lymphoma
}

\author{
Shuichi Nakai ${ }^{1,2}$ (D) Eiji Kiyohara ${ }^{1}$ (D) and Rei Watanabe Ki,3,* $^{1}$ \\ 1 Department of Dermatology, Course of Integrated Medicine, Graduate School of Medicine/Faculty of \\ Medicine, Osaka University, Osaka 565-0871, Japan; 149nakai@derma.med.osaka-u.ac.jp (S.N.); \\ eiji-kiyohara@derma.med.osaka-u.ac.jp (E.K.) \\ 2 Research Department, Maruho Co., Ltd., Kyoto 600-8815, Japan \\ 3 Department of Integrative Medicine for Allergic and Immunological Diseases, Course of Integrated Medicine, \\ Graduate School of Medicine/Faculty of Medicine, Osaka University, Osaka 565-0871, Japan \\ * Correspondence: rwatanabe@derma.med.osaka-u.ac.jp; Tel.: +81-6-6879-3031
}

Citation: Nakai, S.; Kiyohara, E.; Watanabe, R. Malignant and Benign T Cells Constituting Cutaneous T-Cell Lymphoma. Int. J. Mol. Sci. 2021, 22, 12933. https://doi.org/10.3390/ ijms222312933

Academic Editor: Alessandro Pogg

Received: 26 October 2021

Accepted: 26 November 2021

Published: 29 November 2021

Publisher's Note: MDPI stays neutral with regard to jurisdictional claims in published maps and institutional affiliations.

Copyright: (c) 2021 by the authors. Licensee MDPI, Basel, Switzerland. This article is an open access article distributed under the terms and conditions of the Creative Commons Attribution (CC BY) license (https:// creativecommons.org/licenses/by/ $4.0 /)$.
Abstract: Cutaneous T-cell lymphoma (CTCL) is a heterogeneous group of non-Hodgkin lymphoma, including various clinical manifestations, such as mycosis fungoides (MF) and Sézary syndrome (SS). CTCL mostly develops from CD4 T cells with the skin-tropic memory phenotype. Malignant T cells in MF lesions show the phenotype of skin resident memory $\mathrm{T}$ cells $\left(\mathrm{T}_{\mathrm{RM}}\right)$, which reside in the peripheral tissues for long periods and do not recirculate. On the other hand, malignant T cells in SS represent the phenotype of central memory $\mathrm{T}$ cells $\left(\mathrm{T}_{\mathrm{CM}}\right)$, which are characterized by recirculation to and from the blood and lymphoid tissues. The kinetics and the functional characteristics of malignant cells in CTCL are still unclear due, in part, to the fact that both the malignant cells and the T cells exerting anti-tumor activity possess the same characteristics as T cells. Capturing the features of both the malignant and the benign T cells is necessary for understanding the pathogenesis of CTCL and would lead to new therapeutic strategies specifically targeting the skin malignant $\mathrm{T}$ cells or benign T cells.

Keywords: cutaneous T-cell lymphoma; mycosis fungoides; skin resident memory T cells; malignant $\mathrm{T}$ cells; benign $\mathrm{T}$ cells

\section{Introduction}

Cutaneous T-cell lymphoma (CTCL) is a heterogeneous group of non-Hodgkin lymphoma. The clinical manifestation of CTCL is diverse. The most common type of CTCL is mycosis fungoides (MF), presenting with inflammatory skin lesions, such as erythematous patches, plaques, and tumors infiltrated by both malignant and benign T cells [1,2]. The prognosis of early-stage MF is good, and skin-directed therapies can manage the disease activity for the long term in many cases [3]. On the other hand, the advanced-stage MF with the development of tumors, erythroderma, and involvement in the lymph nodes is regarded as showing a poor prognosis. It is thus important to control the disease activity of the early-stage MF to prevent the progression to the advanced stage. Another disease subtype, Sézary syndrome (SS), which is a rare and more aggressive type of CTCL, presents erythroderma, lymphadenopathy, and blood-circulating malignant T cells called Sézary cells from the early phase of disease $[1,4]$. Malignant T cells in CTCL mostly develop from CD4 fraction and possess the skin-tropic memory phenotype, and the lesions are regarded as primarily developing in the skin [1]. The elucidation of molecular and cellular biology in CTCL remains incomplete due, in part, to the fact that malignant T cells and non-malignant infiltrating $\mathrm{T}$ cells are both confined in the same lesional sites. However, recent advances in the next-generation sequencing approaches are adding drastic suggestions concerning the disease pathogenesis. 
Skin is a large barrier tissue which serves to prevent foreign antigens from entering the body. Skin serves as both a structural and an immunological barrier, and healthy human skin contains an estimate of 20 billion memory $T$ cells [5]. Over half of these skin $\mathrm{T}$ cells are understood to remain in the skin for a long period without recirculating to and from blood and lymphoid tissues, and this subpopulation is now called resident memory $\mathrm{T}$ cells $\left(\mathrm{T}_{\mathrm{RM}}\right)[6,7]$. $\mathrm{T}_{\mathrm{RM}}$ provide a stronger local adaptive defense compared to circulating memory $\mathrm{T}$ cells [8-11], and they can exert a sufficient response to the local antigen re-exposure without the aid of circulating T cells [12]. In addition to the function as a local defense against antigens, recent studies suggest that $T_{\mathrm{RM}}$ also provide a systemic response upon re-exposure to antigens by proliferating and baring circulating memory $\mathrm{T}$ cell populations $[13,14]$. Besides infectious diseases, the involvement of skin $T_{R M}$ is now recognized in many cutaneous conditions, such as allergic contact hypersensitivity [15], chronic immune-mediated inflammatory diseases, including vitiligo and psoriasis [16-18], fixed drug eruption [19], and cutaneous malignancies [20]. The engagement of malignant and benign $\mathrm{T}_{\mathrm{RM}}$ in the pathogenesis of CTCL is also being elucidated [7,21,22].

In this review, we first describe the property of skin $\mathrm{T}_{\mathrm{RM}}$, and then provide the characteristics of malignant and benign T cells in MF/SS from the aspects of $\mathrm{T}_{\mathrm{RM}}$ and T-cell phenotypes. We also mention the oncogenic mechanisms and the tumor microenvironment which would affect both malignant and benign T cells in CTCL.

\section{The Development of Skin $T_{R M}$}

Only a few T cells exist in newborn human skin [22], and the population of $\mathrm{T}_{\mathrm{RM}}$ is presumed to be built by the recruitment of circulating $\mathrm{T}$ cells according to the repeated exposure to various antigens. The global characteristic of $T_{R M}$ is tissue retention, and this property can be developed by complex factors, including cytokines, chemokines, their receptors, other cell-surface molecules for tissue homing and retention, and transcription factors.

The cell-surface molecules CD69 and CD103 are the most frequently used markers for recognizing $\mathrm{T}_{\mathrm{RM}}$. CD69 interferes with sphingosine-1-phosphate (S1P) receptor-1, which senses the density gradience of S1P and helps the cells to exit from peripheral tissues to lymphoid organs and blood [23,24]. CD103 is a ligand of E-cadherin which is expressed on epithelial cells [22,25]. However, the existence of $\mathrm{T}_{\mathrm{RM}}$ without the expression of CD69 and/or CD103 has been reported [26,27], and $T_{R M}$ with CD103 expression can also be found in the sites which lack E-cadherin expression, such as the dermis and central nervous system $[22,28]$. Thus, these two molecules are not the universal markers for $\mathrm{T}_{\mathrm{RM}}$.

$\mathrm{T}_{\mathrm{RM}}$ can also be identified by the expression of transcription factors. For instance, skin $\mathrm{T}_{\mathrm{RM}}$ highly express the aryl hydrocarbon receptor (AhR) compared with naïve $\mathrm{T}$ cells and splenic $T$ cells, and AhR presumably contributes to the long-term persistence of epidermal $T_{R M}$ [29]. As for the $T_{R M}$ in other tissues, the maintenance of intestinal CD4 $T_{R M}$ may be related to Hobit and Blimp-1, and the deletion of these molecules results in functional impairment of CD4 $\mathrm{T}_{\mathrm{RM}}$ in the murine model of inflammatory bowel disease (IBD) [30]. Furthermore, circulating effector $\mathrm{T}$ cells expressing Hobit are identified as $\mathrm{T}_{\mathrm{RM}}$ precursors, which preferably form CD8 $\mathrm{T}_{\mathrm{RM}}$ during antigen exposure [31]. These findings might be adapted to skin $\mathrm{T}_{\mathrm{RM}}$ too. The upregulation of Notch [32], Hypoxia-inducible factor$1 \alpha$ [33], Runx3 [34], and basic helix-loop-helix family member E40 [35] have also been reported to be involved in the differentiation and/or maintenance of $\mathrm{T}_{\mathrm{RM}}$. However, as, for instance, lung CD8 $\mathrm{T}_{\mathrm{RM}}$ are shown not to rely on Hobit expression [36], it is also possible that the transcription factors involved in the development and persistence of $\mathrm{T}_{\mathrm{RM}}$ vary among tissues.

While skin $\mathrm{T}_{\mathrm{RM}}$ has a common property with the $\mathrm{T}_{\mathrm{RM}}$ in other organs, they are shown to express distinct molecules related to skin tropism. For instance, CCR6 is highly expressed by CD8 $\mathrm{T}_{\mathrm{RM}}$ in psoriasis lesions $[16,17]$, and $\mathrm{CCR}^{+} \mathrm{CD} 8 \mathrm{~T}_{\mathrm{RM}}$ precursors possibly enter the skin according to the concentration gradient of the ligand CCL20 that is upregulated in psoriatic keratinocytes [37]. The chemokine receptors, such as cutaneous lymphocyteassociated antigen [5], CCR4 [38], CCR8 [39], CCR10 [40], CXCR3 [26,37], and CXCR6 [41] 
have also been reported to play important roles in homing and/or retention in skin. The contribution of some of these molecules to MF pathogenesis and prognosis has been demonstrated $[7,42,43]$, supporting the skin-tropic phenotype of malignant $\mathrm{T}$ cells in MF and the involvement of the tumor microenvironment in disease manifestation, as described in Section 7. However, although the malignant T cells in CTCL are in most cases CD4 $\mathrm{T}$ cells, the information on the development of $\mathrm{CD} 4 \mathrm{~T}_{\mathrm{RM}}$ is still limited.

IL-7 and IL-15 are major cytokines that enable $\mathrm{T}_{\mathrm{RM}}$ to stay in the skin for the long term [44]. IL-7 binds to a heterodimer of the IL-7 receptor $\alpha$ (IL-7R $\alpha$, also named CD127) and IL-2R $\gamma$ (also named CD132) and is involved in T-cell survival and proliferation via downstream molecules, such as Janus kinase (JAK) 1, JAK3, and phosphoinositide 3-kinase (PI3K) [45]. IL-7 is also required for the development [46] and maintenance [47,48] of memory T cells. The receptor of IL-15 is a heterodimer of IL-2R $\beta$ (also named CD122) and CD132 [49]. IL-15 signaling is also transmitted via JAK1 and JAK3 and leads to the promotion of T-cell survival, proliferation, and cytokine production. IL-15 supports the generation of memory $\mathrm{T}$ cells from naïve $\mathrm{T}$ cells and enables memory $\mathrm{T}$ cells to proliferate rapidly in response to antigen re-exposure [50,51]. In the skin, the major sources of IL-7 and IL-15 are fibroblasts and keratinocytes, and the upregulated production of IL-7 is reported in the hair follicles of both MF and SS [52,53], suggesting the role of IL-7 in the recruitment, survival, and proliferation of malignant T cells in CTCL lesions. Deletion of IL-7 or IL-15 attenuates the skin inflammation caused by $\mathrm{CD} 8 \mathrm{~T}_{\mathrm{RM}}$ in the murine contact hypersensitivity model [44], and administration of the CD132-neutralizing antibody decreases the number of CD4 $\mathrm{T}_{\mathrm{RM}}$ in the murine allergic airway models [54]. Besides, the CD122-neutralizing antibody reverses the diseases of a murine model of vitiligo, a chronic skin depigmenting disorder, by the suppression of CD8 $\mathrm{T}_{\mathrm{RM}}$ [55]. As JAK1, JAK3, and the signal transducer and activator of transcription (STAT) are the overlapped molecules which are involved in the signaling pathways of IL-7 and IL-15, they have been hypothesized to play important roles for $\mathrm{T}_{\mathrm{RM}}$ maintenance [56]. At the same time, considering the recent study demonstrating that the development of skin CD8 $\mathrm{T}_{\mathrm{RM}}$ is not efficiently impaired by the administration of a JAK inhibitor in a murine vitiligo model [57], JAK-independent signaling pathways of IL-7/IL-15 are also suggested to be involved in the construction of $\mathrm{T}_{\mathrm{RM}}$. As for CTCL, the activation of the JAK/STAT pathways leads to MF progression accompanied by the upregulation of the cell cycle in malignant $\mathrm{T}$ cells $[58,59]$. The suppressive effects of JAK inhibitors are also reported in the proliferation of CTCL cell lines and SS PBMC T cells $[60,61]$.

\section{The Function of Skin $T_{R M}$}

Among $\mathrm{T}_{\mathrm{RM}}$, the $\mathrm{CD} 8$ fraction has been clarified more thoroughly compared to the CD4 fraction. Just like the general effector CD8 T cells, CD8 $\mathrm{T}_{\mathrm{RM}}$ can be classified into Tc1, Tc2, Tc9, Tc17, and Tc22 by the cytokines they produce [62]. Besides their roles in the defense against pathogens in the barrier tissue, their functional characteristics are known to be related to some inflammatory skin disorders and tumor immunity. For example, in the pathogenesis of vitiligo, IFN $\gamma$-producing CD8 $\mathrm{T}_{\mathrm{RM}}$ has been shown to play a major role $[16,55,63]$. CD49a, which binds to collagen IV in the basement membrane, is reported to be expressed by CD8 $\mathrm{T}_{\mathrm{RM}}$ in vitiligo lesions [16]. $\mathrm{CD} 49 \mathrm{a}^{+} \mathrm{CD} 103^{+} \mathrm{CD} 8 \mathrm{~T}_{\mathrm{RM}}$ are localized to the epidermis, are excelled at IFN $\gamma$ production, and rapidly gain a cytotoxic property in response to IL-15 stimulation. These $\mathrm{T}_{\mathrm{RM}}$ are also involved in alopecia areata (AA), and the granzyme B production from them is related to treatment resistance [64]. Thus, the CD8 $\mathrm{T}_{\mathrm{RM}}$ found in vitiligo and AA are characterized as Tc1-like cells, whereas in the lesional skin of psoriasis, CD8 $\mathrm{T}_{\mathrm{RM}}$ express IL-17A, IL-22, and IFN $\gamma$ [17,65,66]. IL-17A-producing CD8 $\mathrm{T}_{\mathrm{RM}}$ show a high expression level of CCR6, IL-23 receptor, and/or CD49a [16] and remain in the cured sites for the long term [17].

The investigation on the contribution of $\mathrm{CD} 8 \mathrm{~T}_{\mathrm{RM}}$ to the tumor immunity is also progressing rapidly from the aspect of tumor-infiltrating lymphocytes, and tumor-engrafted murine models have revealed the antitumor function of $\mathrm{T}_{\mathrm{RM}}$ in multiple tumor strains $[67,68]$. 
In the actual human solid cancer settings, the property of $\mathrm{T}_{\mathrm{RM}}$ is associated with prognosis. For instance, the infiltration of $\mathrm{CD}_{103}{ }^{+} \mathrm{CD} 8 \mathrm{~T}_{\mathrm{RM}}$ positively correlates with good prognosis in various solid tumors, including breast cancer, esophageal cancer, gastric cancer, lung cancer, and malignant melanoma [69-74]. Various subpopulations of the tumor-infiltrating $\mathrm{T}$ cells express the $\mathrm{T}_{\mathrm{RM}}$ marker $\mathrm{CD} 103$, possibly reacting with E-cadherin expressed by cancer cells and residing in the tumor [68,75], and the expression of CD103 correlates with the cytotoxic function of these T cells with the production of IFN $\gamma$ and granzymes $[67,68,76]$. $\mathrm{T}_{\mathrm{RM}}$ also facilitate the antitumor immunity by the activation of dendritic cells, natural killer cells, and non-specific T cells via the production of the effector cytokines [32,77-79]. The involvement of this population in CTCL is mentioned in Section 6.

Although the characterization of $\mathrm{T}_{\mathrm{RM}}$ has been clarified more in CD8 than in the CD4 fraction, both in the murine models and in humans, research on CD4 $\mathrm{T}_{\mathrm{RM}}$ has also progressed in recent years. Compared to CD8 T cells, CD4 T cells in skin generally express less molecules related to tissue residency and are presumed to be more mobile $[22,80,81]$. At the same time, recent research has demonstrated that $\mathrm{CD} 4 \mathrm{~T}_{\mathrm{RM}}$ are also involved in immune reactions against pathogens such as mycobacterium tuberculosis, herpes simplex virus-2, and the varicella zoster virus and immune-related disorders, including IBD and allergic asthma [30,82-85]. The functional characteristics of CD4 $T_{R M}$ varies depending on the disease condition, mostly in concordance with the characteristics of co-existing CD8 $\mathrm{T}_{\mathrm{RM}}$. The malignant $\mathrm{T}$ cells in MF typically arise from the CD4 fraction and possess the $T_{R M}$ phenotype, especially in the early stage [2,7], and the varied properties of CD4 $T_{R M}$ might be reflected in the disease manifestation of MF.

\section{Distinguishment of Malignant and Benign T Cells in CTCL}

In many cases of the early-stage MF, the majority of $\mathrm{T}$ cells in the skin lesions are benign $T$ cells [86]. These benign $T$ cells are supposed to exert antitumor immunity against malignant cells as tumor-infiltrating $\mathrm{T}$ cells [87]. However, it is difficult to distinguish the benign $\mathrm{T}$ cells from the malignant $\mathrm{T}$ cells because both share the same nature as $\mathrm{T}$ cells. Both malignant and benign $\mathrm{T}$ cells include $\mathrm{T}_{\mathrm{RM}}$ fractions and the definition by $\mathrm{T}_{\mathrm{RM}}$ markers is impossible [7,22]. There are some surrogate cell-surface markers to distinguish between malignant and benign T cells, such as CD5, CD7, and CD26 [88,89].

Among them, the most frequently used marker in the clinical settings is CD7. Loss of CD7 is regarded as the characteristic property of malignant T cells in the skin lesions of MF [90] and the peripheral blood of SS [91]. CD5 is a scavenger receptor cysteinerich family transmembrane glycoprotein expressed on all T cells [92]. Antigen-specific $\mathrm{T}$ cells overexpressing CD5 reportedly persist better as memory $\mathrm{T}$ cells after peripheral activation [93]. The loss of CD5 is sometimes seen in the advanced stages of MF [94]. However, the expression of CD5 is also reported to be higher in the malignant $\mathrm{T}$ cells of SS compared to the benign T cells [89]. Although the expression of this molecule is used in the diagnosis of CTCL, combined with the other information, it would be difficult to reach the diagnosis solely depending on CD5 expression. CD26 is a multifunctional type II cell surface glycoprotein widely expressed on a variety of CD4 T cells [95]. Malignant T cells frequently lose CD26 expression in both the skin and the peripheral blood of SS and $\mathrm{MF}$, and thus can be a good surrogate marker for distinguishing malignant and benign T cells $[88,95]$.

Malignant and benign T cells in skin lesions could also be distinguished by the size and complexity of the cells, not only in histology, but also in flow cytometry analysis $[2,96]$. The large cells with complex nuclear shape are usually regarded as malignant T cells. In practice, however, skin malignant $\mathrm{T}$ cells are as small as their benign counterparts in some MF and other CTCL subtypes. The change of the sizes of malignant $T$ cells could also be experienced. The combination of the cell-surface molecules and cell sizes would be helpful for the detailed distinction.

As the malignant cells in CTCL are rather heterogeneous, with multiple mutant subclones in the same lesions [97,98], and exist along with their benign counterparts, it was 
difficult to identify the common and specific characteristics of the malignant cells. Recently, clarifying malignant $\mathrm{T}$ cells and their properties by high-throughput sequencing analyses, including single-cell RNA sequencing, has enabled the discovery of the common gene expression signatures of malignant $\mathrm{T}$ cells. For instance, highly proliferating malignant $\mathrm{T}$ cells, with the expression of the thymocyte selection-associated, high-mobility group box, share the increased gene expression signature involving cell-cycle progression, proliferation, metabolic processes, and resistance to apoptosis $[99,100]$. The expression of multiple inhibitory receptors is also confirmed in benign T cells from the advanced-stage MF [100]. While it would be currently difficult to separate the live malignant and benign $\mathrm{T}$ cells depending on these intracellular molecules, the further progression in analytical techniques would enable the elucidation of the biological characteristics of both the malignant and the benign $T$ cells in the near future.

\section{Malignant T Cells in CTCL}

The malignant $T$ cells in the early-stage MF skin lesions typically represent the $T_{R M}$ phenotype [7]. In a rare case of CD8 MF, the malignant T cells were also demonstrated to have CD8 the $T_{R M}$ phenotype, characterized by the high expression of CD69 and CD103 and the low expression of CD62L and CCR7 [101]. On the other hand, malignant T cells from the skin and blood of SS patients typically show the $\mathrm{T}_{\mathrm{CM}}$ phenotype $[7,102]$. The recirculation pattern of $\mathrm{T}_{\mathrm{CM}}$ is similar to that of the naïve $\mathrm{T}$ cells, and they migrate between the blood and the secondary lymphoid organs [103]. $\mathrm{T}_{\mathrm{CM}}$ are also understood to enter the peripheral tissues according to their tissue-tropic molecules [104]. The difference in the clinical appearance and the sensitivity to the systemic therapies can partially be explained by this phenotypic difference of malignant T cells in CTCL [22] (Figure 1).
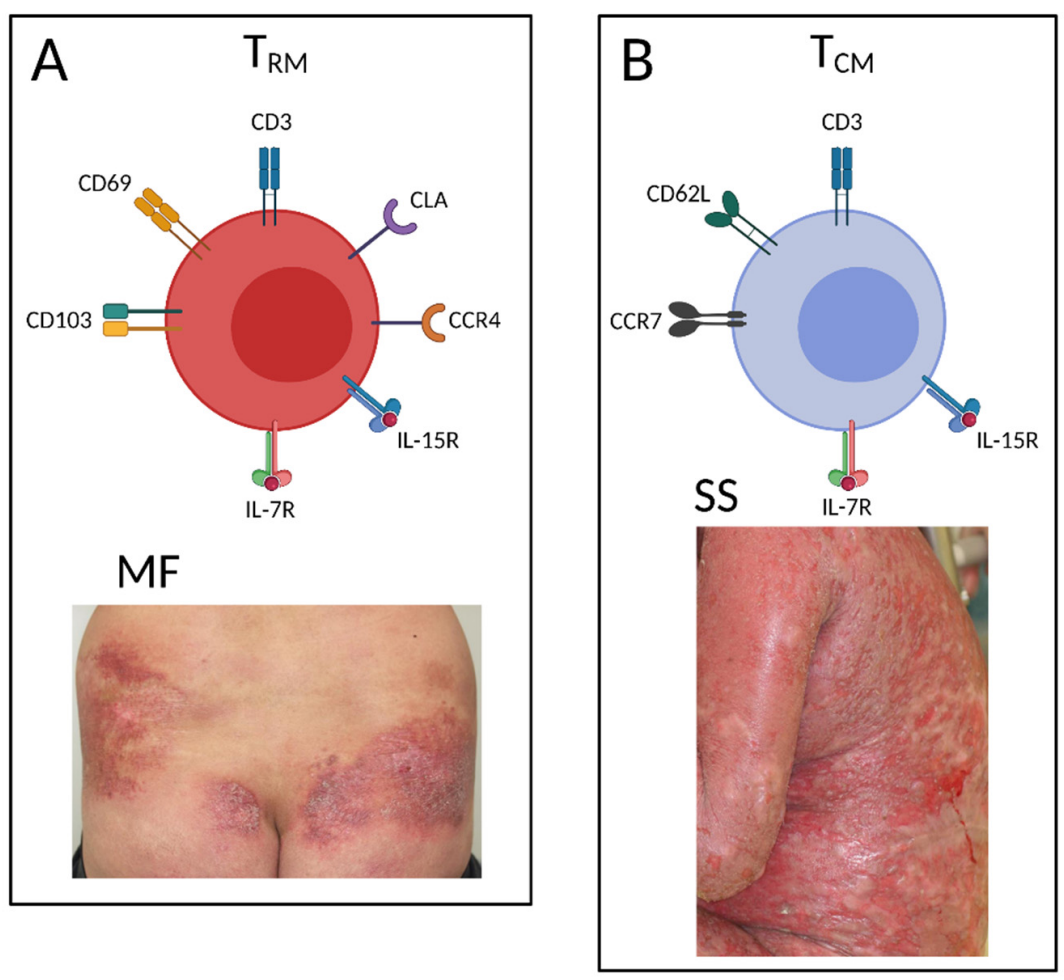

Figure 1. The cell-surface molecules characteristic of the malignant $T$ cells found in mycosis fungoides (MF) and Sézary syndrome (SS). (A) The malignant T cells in a well-demarcated patch or plaque lesions of MF typically show the resident memory $T$ cells $\left(\mathrm{T}_{\mathrm{RM}}\right)$ phenotype with CD69 and CD103 expression. (B) The malignant T cells found in diffuse erythema of SS typically show the central memory $\mathrm{T}$ cells $\left(\mathrm{T}_{\mathrm{CM}}\right)$ phenotype with CCR7 and CD62L expression. Created by BioRender.com. 
As for the immunophenotype, while the malignant $T$ cells generally represent the Th1 profile in the early stage of MF, they shift to Th2 property according to the disease progression. For instance, in the patch to plaque stage of $\mathrm{MF}$, the ratio of the cells positive for the Th1 master regulator t-box family of transcription factors (t-bet) is higher than that of the positive for the Th2 master regulator gata-binding factor 3 (gata-3). In contrast, gata- 3 outdoes t-bet expression in the tumor stage of MF [86]. As the Th2 cytokine, the lesional IL4 expression, which is comparable with healthy control skin in the early stage, gets higher in the advanced stage of MF [105]. The malignant T cells in SS are also understood to show a Th2 profile with a high IL-4/IL-13 expression and a low TNF $\alpha /$ IFN $\gamma$ expression [106]. Recent research demonstrates that the phenotypical change of the malignant $\mathrm{T}$ cells is affected by the tumor microenvironment (TME), as mentioned in Section 7.

IL-7 is high in the lesional skin of CTCL, both in the mRNA and the protein level, and this skin-derived IL-7 contributes to the proliferation of malignant T cells with high IL-7R $\alpha$ expression. Another study revealed that IL-15 prolongs the survival of malignant T cells from SS [107]. IL-15 is highly expressed in CTCL lesions and blood, including the T cells [52], and the overexpression of IL-15 in CTCL T cells is reported to be due to the disruption of epigenetic modification [108]. Interestingly, the deletion of IL-7 suppresses the development of the CD4 $\mathrm{T}_{\mathrm{RM}}$ population in a murine CTCL model, which represents the pathological manifestation mimicking MF, where the epidermotropic $\mathrm{T}$ cells show increased IL-7R $\alpha$ expression [44]. IL-15 transgenic mice also develop skin lesions representing the pathological characteristics of MF [108]. These results imply the importance of IL-7 and IL-15 in the development of malignant $\mathrm{T}_{\mathrm{RM}}$ in CTCL, especially in MF.

Recently, two models of the $\mathrm{T}_{\mathrm{RM}}$ cell lineage divergence have been reported [109]. The first model is called the 'local divergence' model, which is based on the concept that the circulating memory precursor pool is composed of the cells that are equal in their potential to contribute to both the $\mathrm{T}_{\mathrm{RM}}$ cell pool and the circulating memory T-cell pool $[110,111]$. According to this concept, $\mathrm{T}_{\mathrm{RM}}$ are replenished rather randomly from the memory precursors in circulation by the assistance of the microenvironment, including the enrichment of TGF $\beta$ [112,113], IL-7, and IL-15 [44,111,114] signaling. The other model is called the 'systemic divergence' model, which is based on the concept that the memory precursor cells are destined to differentiate into $\mathrm{T}_{\mathrm{RM}}$ or circulating memory $\mathrm{T}$ cells within the lymphoid tissues or blood $[34,115]$. In this concept, the cellular fate of the $\mathrm{T}_{\mathrm{RM}}$ precursors is already decided at the time of differentiation into memory precursors, possibly shifting to the gene expression profiles similar to those of $\mathrm{T}_{\mathrm{RM}}[115,116]$ and waiting for the differentiation into $\mathrm{T}_{\mathrm{RM}}$ until the local inflammation or antigen exposure occurs. The disease course of CTCL, including lesion expansion both in size and in number and the changes of clinical manifestation, and the fact that multiple subclones on the same evolutionary tree of T-cell clones are found in different skin lesions, regardless of the well-demarcated patch/plaques or ill-demarcated tumors, may possibly be explained by the 'systemic divergence' model. In other words, parts of the $\mathrm{T}_{\mathrm{RM}}$ precursors might acquire or already have acquired the malignant property in the lymph nodes or blood before infiltrating into the skin and forming MF lesions. Further studies are awaited as the reliable methods for distinguishing $\mathrm{T}_{\mathrm{RM}}$ precursors from the other memory $\mathrm{T}$ cell precursors have not been established. Revealing the relationship between $\mathrm{T}_{\mathrm{RM}}$ precursors and CTCL development might lead to the establishment of predicting indexes for disease progression.

\section{Benign T Cells in CTCL}

The non-clonal benign T cells in CTCL lesions are understood to exert antitumor immunity against their malignant counterparts. The early-stage MF lesions contain benign Th1 cells and Tc1 cells $[86,117]$, which are supposed to produce cytotoxic molecules, such as granzymes, perforin, and IFN $\gamma$. Thus, benign T cells surrounding CTCL lesions might play a role in suppressing the progression of CTCL. While the expression of $\mathrm{T}_{\mathrm{RM}}$ markers, especially CD103, in tumor-infiltrating $\mathrm{T}$ cells is associated with a stronger antitumor effect in various solid malignant tumors, as described above [69-74], benign T cells in CTCL lesions 
possess less $\mathrm{T}_{\mathrm{RM}}\left(\mathrm{CD} 69^{+} \mathrm{CD} 103^{+}\right)$phenotype $[97,118]$. From the perspective of suppressive functions in antitumor immunity, these benign Th1 cells more frequently express immune checkpoint molecules, such as the programmed cell death 1 , lymphocyte activation gene 3 (LAG-3), and cytotoxic T-lymphocyte-associated protein 4 [97]. The benign Tc1 cells also highly express LAG-3, consistent with their less inflammatory phenotype, with the decreased production of cytotoxic molecules [97]. Furthermore, as the disease progresses, CTCL lesions are shifted to the Th2 environment [119]. In skin, Th2 cells are dominated in the dermal fraction with less expression of $\mathrm{T}_{\mathrm{RM}}$ markers [22]. Th2 cytokines have been reported to show tumor-promoting effects in some solid tumors [120-122], and among these cytokines, IL-13 and thymic stromal lymphopoietin (TSLP) are shown to be directly involved in the progression of CTCL. These studies imply that benign $\mathrm{T}_{\mathrm{RM}}$ in CTCL lesions are decreased both in number and antitumor function with stronger immune-suppressive property. The profiles of benign $\mathrm{T}$ cells also change according to the disease progression.

CTCL is treated with various modalities, including topical therapies, ultraviolet (UV) therapies, radiation therapies, and systemic therapies [94]. It has been reported that the cytokine profile of benign $\mathrm{T}$ cells is significantly changed before and after effective treatments. While IL-4 production is dominant in benign T cells before treatments, it starts producing IL-2, IFN $\gamma$, and TNF $\alpha$ after treatments such as UV, alemtuzumab, and gemcitabine [106]. It has also been revealed that the expression of Th1-related genes, including CXCL9, CXCL10, and CXCL11, correlates with the number of benign T cells in the cured lesions after psoralen and UVA therapy [21], which suggests that the modified expression profile of cytokines and chemokines in the skin microenvironment may lead to the profile shift of benign T cells from Th2 to Th1 after treatments.

A recent study revealed that c-Kit ${ }^{+}$dendritic cells produce CCL18, which recruits benign Th2 cells, including both $\mathrm{T}_{\mathrm{RM}}$ and non- $\mathrm{T}_{\mathrm{RM}}$, and creates an inflammatory synapse among dendritic cells, benign $\mathrm{T}$ cells, and malignant $\mathrm{T}$ cells [21]. Interactions between the benign $\mathrm{OX} 40^{+} \mathrm{Th} 2$ cells and the $\mathrm{OX}_{40 \mathrm{~L}^{+}} \mathrm{c}-\mathrm{Kit}^{+}$dendritic cells, and between CD40 on benign Th2 cells and CD40L on malignant $\mathrm{T}$ cells, may drive the antigen-independent activation of benign Th2 cells, leading to the visible skin inflammation. This inflammation is diminished after UV therapy, with the loss of correlation between the CCL18 and benign T cells in the CTCL lesions. Considering other studies suggesting that CCL18 expression from macrophages and dendritic cells in the lesions is related to the severity and progression of CTCL [123,124], the benign Th2 cells within CTCL lesions might serve as pro-tumorigenic $\mathrm{T}$ cells and might be associated with the tumor progression of CTCL.

\section{Tumor Microenvironment in CTCL}

The difficulty in the clarification of malignant and benign $\mathrm{T}$ cells can be caused by the effects of TME on both the malignant and the benign T cells $[125,126]$. Among the various cells constituting TME, for example, tumor-associated macrophages (TAM) are increased in MF and SS lesions with the increased expression of CCL18 and CCL22, which promote a Th2-biased microenvironment, as mentioned above [123,127]. Indeed, malignant T cells of CTCL highly express CCR4, which is a receptor of CCL18 and CCL22 and also serves as a $\mathrm{T}_{\mathrm{RM}}$ marker $[7,97]$. Additionally, in a murine CTCL model, depletion of TAM results in a decrease in tumor size and an increase in tumor-infiltrating CD8 T cells and in the level of antitumor cytokines [128].

Cancer-associated fibroblasts (CAF) isolated from the lesional skin of CTCL are also reported to promote tumor progression and the Th2 environment by the production of various mediators $[129,130]$. Among these mediators, eotaxins are considered to contribute to tumor migration via interaction with CCR $3^{+}$lymphocytes and the promotion of the Th2 environment in CTCL [129]. It has also been reported that CAF decrease Th1 chemokine, leading to a Th2-dominant microenvironment, via the production of the herpes virus entry mediator (HVEM) [130]. Another study suggests that CAF protect the malignant T cells from chemotherapy-induced cell death and increase their migration by the interaction of CXCL12 with CXCR4 expressed on the malignant T cells [131]. Actually, normal fibroblasts 
and CAF show the opposite effects on the CTCL cell line [132]. Normal fibroblasts suppress the expression of MF biomarkers such as twist-related protein 1 (TWIST1) and thymocyte selection associated high mobility group box (TOX) and enhance the expression of the Th1related gene, including IFN $\gamma$ and T-bet, although CAF promote the expression of these molecules and suppress the expression of the Th1-related gene. These studies suggest that normal fibroblasts can suppress the expression of disease-promoting genes from the malignant $\mathrm{T}$ cells in MF and create an unfavorable environment for their proliferation. The indolent disease progression in the early stage of MF may be at least partially explained by these tumor-suppressing effects of normal fibroblasts.

From the aspects of the molecules, the cytokines and chemokines which contribute to the recruitment and differentiation of TME-related cells, including TAM, CAF, and $\mathrm{T}_{\mathrm{RM}}$ (both benign and malignant), would also be counted as constituting TME. IL-7, IL-15, and TGF $\beta$ can develop the population of both the malignant and the benign $\mathrm{T}_{\mathrm{RM}}[52,107,108,112,113]$, and TGF $\beta$ helps the induction of TAM and CAF $[125,133]$. TSLP, IL-4, and IL-13 would accelerate the Th2-dominant environment [134]. As for the association of chemokines and their receptors, the infiltration of malignant $\mathrm{T}$ cells and the Th2biased microenvironment are enhanced by eotaxins and HVEM from CAF, keratinocytes, and dendritic cells $[129,133]$. Furthermore, $T_{R M}$ expressing CCR4, CCR8, and CCR10 can be recruited in the skin, attracted by CCL17, CCL18, CCL22, and CCL27, which are produced by the TAM, keratinocytes, and dendritic cells [123,124,127,135,136] (Figure 2).

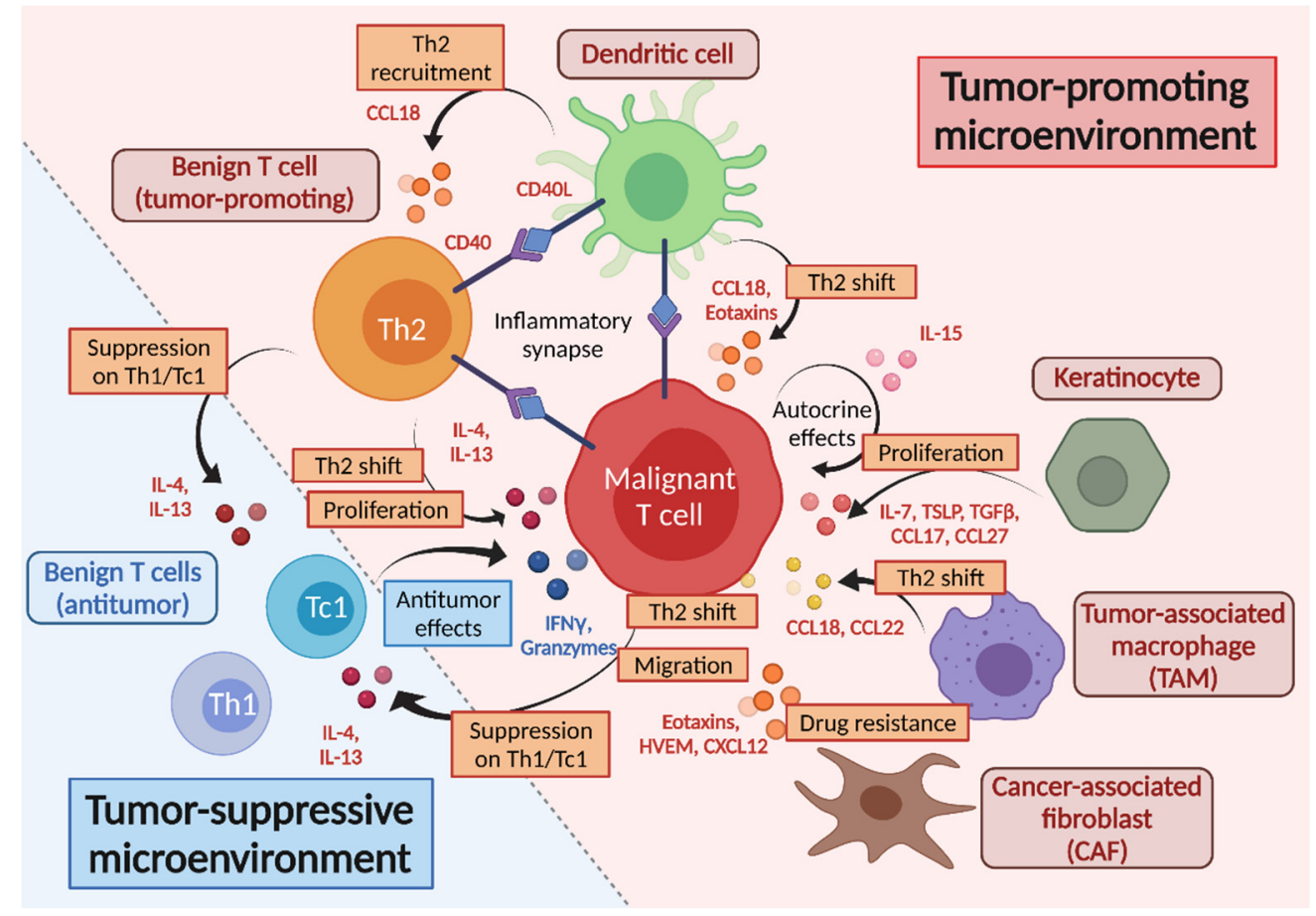

Figure 2. Tumor microenvironment in CTCL. The recruitment and proliferation of malignant T cells are promoted by chemokines and cytokines from the tumor-constituting cells, including TAM, CAF, dendritic cells, keratinocytes, and Th2 cells. IL-15 from the malignant T cells works in the autocrine manner too. Inflammatory synapses are formed among dendritic cells, benign Th2, and malignant $\mathrm{T}$ cells and contribute to Th2-biased microenvironment and tumor progression. Benign Th1 and Tc1 cells exert antitumor effects by producing IFN $\gamma$ and granzymes, while they are suppressed by Th2 cytokines, such as IL-4 and IL-13, which benign Th2 and malignant T cells produce. Tumor-promoting molecules are represented in red, and tumor-suppressive molecules are indicated in blue.

Accordingly, TME in CTCL leads to the Th2-biased condition, affecting both malignant and benign $\mathrm{T}$ cells in the lesions, which would promote the expansion of malignant $\mathrm{T}$ cells 
and suppress the antitumor activities of benign $\mathrm{T}$ cells, sometimes making the distinction of these two fractions obscure.

\section{Conclusions}

Based on these findings, the characteristics of malignant and benign T cells in CTCL are summarized as below.

- $\quad$ The malignant $T$ cells in MF typically possess the $T_{R M}$ phenotype with a stronger reactive property to skin-derived IL-7 and/or IL-15.

- Malignant T-cell population in MF consists of multiple subclones sometimes common between different lesions, suggesting that it might develop according to the repeated somatic mutations both before and after entering the skin.

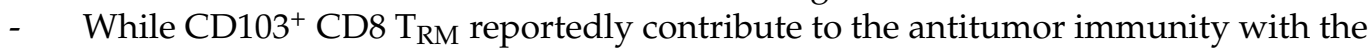
production of IFN $\gamma$ and granzymes in multiple solid cancers, benign T cells in CTCL lesions possess less $\mathrm{T}_{\mathrm{RM}}$ phenotype with Th2-biased suppressive property.

- As TME, the recruitment and proliferation of malignant $T$ cells in skin can be supported by cytokines and chemokines in the skin. In addition, the related cells, such as TAM and CAF, are involved in the promotion of a Th2-biased microenvironment, affecting both malignant and benign T cells in CTCL.

Capturing the features of malignant and benign T cells in CTCL is necessary for understanding the pathogenesis of CTCL and would hopefully lead to new therapeutic strategies specifically targeting the skin malignant $\mathrm{T}$ cells or benign $\mathrm{T}$ cells.

Author Contributions: Conceptualization, S.N., E.K. and R.W.; writing-original draft preparation, S.N.; writing - review and editing, S.N., E.K. and R.W.; visualization, S.N., E.K. and R.W.; supervision, E.K. and R.W. All authors have read and agreed to the published version of the manuscript.

Funding: This research received no external funding.

Institutional Review Board Statement: The collection of clinical pictures was conducted according to the guidelines of the Declaration of Helsinki and approved by the Institutional Review Board of Osaka University Hospital (approval number 20108).

Informed Consent Statement: Informed consent was obtained from all subjects involved in this article.

Conflicts of Interest: The authors declare no conflict of interest.

\section{References}

1. Willemze, R.; Cerroni, L.; Kempf, W.; Berti, E.; Facchetti, F.; Swerdlow, S.H.; Jaffe, E.S. The 2018 update of the WHO-EORTC classification for primary cutaneous lymphomas. Blood 2019, 133, 1703-1714. [CrossRef] [PubMed]

2. Clark, R.A.; Shackelton, J.B.; Watanabe, R.; Calarese, A.; Yamanaka, K.; Campbell, J.J.; Teague, J.E.; Kuo, H.P.; Hijnen, D.; Kupper, T.S. High-scatter T cells: A reliable biomarker for malignant T cells in cutaneous T-cell lymphoma. Blood 2011, 117, 1966-1976. [CrossRef]

3. Agar, N.S.; Wedgeworth, E.; Crichton, S.; Mitchell, T.J.; Cox, M.; Ferreira, S.; Robson, A.; Calonje, E.; Stefanato, C.M.; Wain, E.M.; et al. Survival outcomes and prognostic factors in mycosis fungoides/Sezary syndrome: Validation of the revised International Society for Cutaneous Lymphomas/European Organisation for Research and Treatment of Cancer staging proposal. J. Clin. Oncol. 2010, 28, 4730-4739. [CrossRef]

4. Najidh, S.; Tensen, C.P.; van der Sluijs-Gelling, A.J.; Teodosio, C.; Cats, D.; Mei, H.; Kuipers, T.B.; Out-Luiting, J.J.; Zoutman, W.H.; van Hall, T.; et al. Improved Sezary cell detection and novel insights into immunophenotypic and molecular heterogeneity in Sezary syndrome. Blood 2021. [CrossRef] [PubMed]

5. Clark, R.A.; Chong, B.; Mirchandani, N.; Brinster, N.K.; Yamanaka, K.; Dowgiert, R.K.; Kupper, T.S. The vast majority of CLA+ T cells are resident in normal skin. J. Immunol. 2006, 176, 4431-4439. [CrossRef]

6. Clark, R.A.; Chong, B.F.; Mirchandani, N.; Yamanaka, K.; Murphy, G.F.; Dowgiert, R.K.; Kupper, T.S. A novel method for the isolation of skin resident T cells from normal and diseased human skin. J. Investig. Dermatol. 2006, 126, 1059-1070. [CrossRef] [PubMed]

7. Clark, R.A.; Watanabe, R.; Teague, J.E.; Schlapbach, C.; Tawa, M.C.; Adams, N.; Dorosario, A.A.; Chaney, K.S.; Cutler, C.S.; Leboeuf, N.R.; et al. Skin effector memory T cells do not recirculate and provide immune protection in alemtuzumab-treated CTCL patients. Sci. Transl. Med. 2012, 4, 117ra117. [CrossRef] 
8. Khalil, S.; Bardawil, T.; Kurban, M.; Abbas, O. Tissue-resident memory T cells in the skin. Inflamm. Res. 2020, 69, 245-254. [CrossRef] [PubMed]

9. Schenkel, J.M.; Masopust, D. Tissue-resident memory T cells. Immunity 2014, 41, 886-897. [CrossRef]

10. Mueller, S.N.; Mackay, L.K. Tissue-resident memory T cells: Local specialists in immune defence. Nat. Rev. Immunol. 2016, 16, 79-89. [CrossRef]

11. Carbone, F.R. Tissue-Resident Memory T Cells and Fixed Immune Surveillance in Nonlymphoid Organs. J. Immunol. 2015, 195, 17-22. [CrossRef] [PubMed]

12. Jiang, X.; Clark, R.A.; Liu, L.; Wagers, A.J.; Fuhlbrigge, R.C.; Kupper, T.S. Skin infection generates non-migratory memory CD8 ${ }^{+}$ $\mathrm{T}(\mathrm{RM})$ cells providing global skin immunity. Nature 2012, 483, 227-231. [CrossRef] [PubMed]

13. Behr, F.M.; Parga-Vidal, L.; Kragten, N.A.M.; van Dam, T.J.P.; Wesselink, T.H.; Sheridan, B.S.; Arens, R.; van Lier, R.A.W.; Stark, R.; van Gisbergen, $\mathrm{K}$. Tissue-resident memory $\mathrm{CD} 8\left(^{+}\right) \mathrm{T}$ cells shape local and systemic secondary T cell responses. Nat. Immunol. 2020, 21, 1070-1081. [CrossRef] [PubMed]

14. Fonseca, R.; Beura, L.K.; Quarnstrom, C.F.; Ghoneim, H.E.; Fan, Y.; Zebley, C.C.; Scott, M.C.; Fares-Frederickson, N.J.; Wijeyesinghe, S.; Thompson, E.A.; et al. Developmental plasticity allows outside-in immune responses by resident memory T cells. Nat. Immunol. 2020, 21, 412-421. [CrossRef]

15. Gaide, O.; Emerson, R.O.; Jiang, X.; Gulati, N.; Nizza, S.; Desmarais, C.; Robins, H.; Krueger, J.G.; Clark, R.A.; Kupper, T.S. Common clonal origin of central and resident memory T cells following skin immunization. Nat. Med. 2015, 21, 647-653. [CrossRef] [PubMed]

16. Cheuk, S.; Schlums, H.; Gallais Serezal, I.; Martini, E.; Chiang, S.C.; Marquardt, N.; Gibbs, A.; Detlofsson, E.; Introini, A.; Forkel, M.; et al. CD49a Expression Defines Tissue-Resident CD8 $\left(^{+}\right)$T Cells Poised for Cytotoxic Function in Human Skin. Immunity 2017, 46, 287-300. [CrossRef]

17. Cheuk, S.; Wiken, M.; Blomqvist, L.; Nylen, S.; Talme, T.; Stahle, M.; Eidsmo, L. Epidermal Th22 and Tc17 cells form a localized disease memory in clinically healed psoriasis. J. Immunol. 2014, 192, 3111-3120. [CrossRef] [PubMed]

18. Serezal, I.G.; Classon, C.; Cheuk, S.; Barrientos-Somarribas, M.; Wadman, E.; Martini, E.; Chang, D.; Landen, N.X.; Ehrstrom, M.; Nylen, S.; et al. Resident T Cells in Resolved Psoriasis Steer Tissue Responses that Stratify Clinical Outcome. J. Investig. Dermatol. 2018, 138, 1754-1763. [CrossRef]

19. Mizukawa, Y.; Yamazaki, Y.; Teraki, Y.; Hayakawa, J.; Hayakawa, K.; Nuriya, H.; Kohara, M.; Shiohara, T. Direct evidence for interferon-gamma production by effector-memory-type intraepidermal T cells residing at an effector site of immunopathology in fixed drug eruption. Am. J. Pathol. 2002, 161, 1337-1347. [CrossRef]

20. Edwards, J.; Wilmott, J.S.; Madore, J.; Gide, T.N.; Quek, C.; Tasker, A.; Ferguson, A.; Chen, J.B.; Hewavisenti, R.; Hersey, P.; et al. CD103 $\left(^{+}\right)$Tumor-Resident CD8 $\left(^{+}\right)$T Cells Are Associated with Improved Survival in Immunotherapy-Naive Melanoma Patients and Expand Significantly During Anti-PD-1 Treatment. Clin. Cancer Res. 2018, 24, 3036-3045. [CrossRef]

21. Vieyra-Garcia, P.; Crouch, J.D.; O’Malley, J.T.; Seger, E.W.; Yang, C.H.; Teague, J.E.; Vromans, A.M.; Gehad, A.; Win, T.S.; Yu, Z.; et al. Benign T cells drive clinical skin inflammation in cutaneous T cell lymphoma. JCI Insight 2019, 4, e124233. [CrossRef] [PubMed]

22. Watanabe, R.; Gehad, A.; Yang, C.; Scott, L.L.; Teague, J.E.; Schlapbach, C.; Elco, C.P.; Huang, V.; Matos, T.R.; Kupper, T.S.; et al. Human skin is protected by four functionally and phenotypically discrete populations of resident and recirculating memory $\mathrm{T}$ cells. Sci. Transl. Med. 2015, 7, 279ra39. [CrossRef] [PubMed]

23. Bankovich, A.J.; Shiow, L.R.; Cyster, J.G. CD69 suppresses sphingosine 1-phosophate receptor-1 (S1P1) function through interaction with membrane helix 4. J. Biol. Chem. 2010, 285, 22328-22337. [CrossRef] [PubMed]

24. Mackay, L.K.; Braun, A.; Macleod, B.L.; Collins, N.; Tebartz, C.; Bedoui, S.; Carbone, F.R.; Gebhardt, T. Cutting edge: CD69 interference with sphingosine-1-phosphate receptor function regulates peripheral T cell retention. J. Immunol. 2015, 194, 2059-2063. [CrossRef] [PubMed]

25. Cepek, K.L.; Shaw, S.K.; Parker, C.M.; Russell, G.J.; Morrow, J.S.; Rimm, D.L.; Brenner, M.B. Adhesion between epithelial cells and T lymphocytes mediated by E-cadherin and the alpha E beta 7 integrin. Nature 1994, 372, 190-193. [CrossRef] [PubMed]

26. Bergsbaken, T.; Bevan, M.J. Proinflammatory microenvironments within the intestine regulate the differentiation of tissue-resident CD8 $\left(^{+}\right)$T cells responding to infection. Nat. Immunol. 2015, 16, 406-414. [CrossRef]

27. Steinert, E.M.; Schenkel, J.M.; Fraser, K.A.; Beura, L.K.; Manlove, L.S.; Igyarto, B.Z.; Southern, P.J.; Masopust, D. Quantifying Memory CD8 T Cells Reveals Regionalization of Immunosurveillance. Cell 2015, 161, 737-749. [CrossRef]

28. Wakim, L.M.; Woodward-Davis, A.; Bevan, M.J. Memory T cells persisting within the brain after local infection show functional adaptations to their tissue of residence. Proc. Natl. Acad. Sci. USA 2010, 107, 17872-17879. [CrossRef]

29. Zaid, A.; Mackay, L.K.; Rahimpour, A.; Braun, A.; Veldhoen, M.; Carbone, F.R.; Manton, J.H.; Heath, W.R.; Mueller, S.N. Persistence of skin-resident memory T cells within an epidermal niche. Proc. Natl. Acad. Sci. USA 2014, 111, 5307-5312. [CrossRef]

30. Zundler, S.; Becker, E.; Spocinska, M.; Slawik, M.; Parga-Vidal, L.; Stark, R.; Wiendl, M.; Atreya, R.; Rath, T.; Leppkes, M.; et al. Hobit- and Blimp-1-driven CD4(+) tissue-resident memory T cells control chronic intestinal inflammation. Nat. Immunol. 2019, 20, 288-300. [CrossRef]

31. Parga-Vidal, L.; Behr, F.M.; Kragten, N.A.M.; Nota, B.; Wesselink, T.H.; Kavazovic, I.; Covill, L.E.; Schuller, M.B.P.; Bryceson, Y.T.; Wensveen, F.M.; et al. Hobit identifies tissue-resident memory T cell precursors that are regulated by Eomes. Sci. Immunol. 2021, 6, eabg3533. [CrossRef] 
32. Hombrink, P.; Helbig, C.; Backer, R.A.; Piet, B.; Oja, A.E.; Stark, R.; Brasser, G.; Jongejan, A.; Jonkers, R.E.; Nota, B.; et al. Programs for the persistence, vigilance and control of human $C D 8\left(^{+}\right)$lung-resident memory T cells. Nat. Immunol. 2016, 17, 1467-1478. [CrossRef]

33. Liikanen, I.; Lauhan, C.; Quon, S.; Omilusik, K.; Phan, A.T.; Bartroli, L.B.; Ferry, A.; Goulding, J.; Chen, J.; Scott-Browne, J.P.; et al. Hypoxia-inducible factor activity promotes antitumor effector function and tissue residency by CD8 ${ }^{+} \mathrm{T}$ cells. J. Clin. Investig. 2021, 131, e143729. [CrossRef]

34. Milner, J.J.; Toma, C.; Yu, B.F.; Zhang, K.; Omilusik, K.; Phan, A.T.; Wang, D.P.; Getzler, A.J.; Nguyen, T.; Crotty, S.; et al. Runx3 programs CD8(+) T cell residency in non-lymphoid tissues and tumours. Nature 2017, 552, 253-257. [CrossRef] [PubMed]

35. Li, C.F.; Zhu, B.B.; Son, Y.M.; Wang, Z.; Jiang, L.; Xiang, M.; Ye, Z.Q.; Beckermann, K.E.; Wu, Y.; Jenkins, J.W.; et al. The Transcription Factor Bhlhe40 Programs Mitochondrial Regulation of Resident CD8 $\left(^{+}\right.$) T Cell Fitness and Functionality (vol 51, pg 491.e1, 2019). Immunity 2020, 52, 201-202. [CrossRef] [PubMed]

36. Behr, F.M.; Kragten, N.A.M.; Wesselink, T.H.; Nota, B.; van Lier, R.A.W.; Amsen, D.; Stark, R.; Hombrink, P.; van Gisbergen, K. Blimp-1 Rather Than Hobit Drives the Formation of Tissue-Resident Memory CD8( $\left.{ }^{+}\right)$T Cells in the Lungs. Front. Immunol. 2019, 10, 400. [CrossRef] [PubMed]

37. Homey, B.; Dieu-Nosjean, M.C.; Wiesenborn, A.; Massacrier, C.; Pin, J.J.; Oldham, E.; Catron, D.; Buchanan, M.E.; Muller, A.; Malefyt, R.D.; et al. Up-regulation of macrophage inflammatory protein-3 alpha/CCL20 and CC chemokine receptor 6 in psoriasis. J. Immunol. 2000, 164, 6621-6632. [CrossRef]

38. Campbell, J.J.; Haraldsen, G.; Pan, J.; Rottman, J.; Qin, S.; Ponath, P.; Andrew, D.P.; Warnke, R.; Ruffing, N.; Kassam, N.; et al. The chemokine receptor CCR4 in vascular recognition by cutaneous but not intestinal memory T cells. Nature 1999, 400, 776-780. [CrossRef] [PubMed]

39. McCully, M.L.; Ladell, K.; Andrews, R.; Jones, R.E.; Miners, K.L.; Roger, L.; Baird, D.M.; Cameron, M.J.; Jessop, Z.M.; Whitaker, I.S.; et al. CCR8 Expression Defines Tissue-Resident Memory T Cells in Human Skin. J. Immunol. 2018, 200, 1639-1650. [CrossRef]

40. Xia, M.; Hu, S.; Fu, Y.; Jin, W.; Yi, Q.; Matsui, Y.; Yang, J.; McDowell, M.A.; Sarkar, S.; Kalia, V.; et al. CCR10 regulates balanced maintenance and function of resident regulatory and effector T cells to promote immune homeostasis in the skin. J. Allergy Clin. Immunol. 2014, 134, 634-644.e610. [CrossRef] [PubMed]

41. Zaid, A.; Hor, J.L.; Christo, S.N.; Groom, J.R.; Heath, W.R.; Mackay, L.K.; Mueller, S.N. Chemokine Receptor-Dependent Control of Skin Tissue-Resident Memory T Cell Formation. J. Immunol. 2017, 199, 2451-2459. [CrossRef]

42. Nicolay, J.P.; Albrecht, J.D.; Alberti-Violetti, S.; Berti, E. CCR4 in cutaneous T-cell lymphoma: Therapeutic targeting of a pathogenic driver. Eur. J. Immunol. 2021, 51, 1660-1671. [CrossRef] [PubMed]

43. Ikeda, S.; Kitadate, A.; Ito, M.; Abe, F.; Nara, M.; Watanabe, A.; Takahashi, N.; Miyagaki, T.; Sugaya, M.; Tagawa, H. Disruption of CCL20-CCR6 interaction inhibits metastasis of advanced cutaneous T-cell lymphoma. Oncotarget 2016, 7, 13563-13574. [CrossRef] [PubMed]

44. Adachi, T.; Kobayashi, T.; Sugihara, E.; Yamada, T.; Ikuta, K.; Pittaluga, S.; Saya, H.; Amagai, M.; Nagao, K. Hair follicle-derived IL-7 and IL-15 mediate skin-resident memory T cell homeostasis and lymphoma. Nat. Med. 2015, 21, 1272-1279. [CrossRef] [PubMed]

45. Mackall, C.L.; Fry, T.J.; Gress, R.E. Harnessing the biology of IL-7 for therapeutic application. Nat. Rev. Immunol. 2011, 11, 330-342. [CrossRef] [PubMed]

46. Puel, A.; Ziegler, S.F.; Buckley, R.H.; Leonard, W.J. Defective IL7R expression in T-B+NK+ severe combined immunodeficiency. Nat. Genet. 1998, 20, 394-397. [CrossRef]

47. Schluns, K.S.; Kieper, W.C.; Jameson, S.C.; Lefrancois, L. Interleukin-7 mediates the homeostasis of naive and memory CD8 T cells in vivo. Nat. Immunol. 2000, 1, 426-432. [CrossRef]

48. Chetoui, N.; Boisvert, M.; Gendron, S.; Aoudjit, F. Interleukin-7 promotes the survival of human CD4 ${ }^{+}$effector/memory T cells by up-regulating Bcl-2 proteins and activating the JAK/STAT signalling pathway. Immunology 2010, 130, 418-426. [CrossRef]

49. Jabri, B.; Abadie, V. IL-15 functions as a danger signal to regulate tissue-resident T cells and tissue destruction. Nat. Rev. Immunol. 2015, 15, 771-783. [CrossRef]

50. Cieri, N.; Camisa, B.; Cocchiarella, F.; Forcato, M.; Oliveira, G.; Provasi, E.; Bondanza, A.; Bordignon, C.; Peccatori, J.; Ciceri, F.; et al. IL-7 and IL-15 instruct the generation of human memory stem T cells from naive precursors. Blood 2013, 121, 573-584. [CrossRef]

51. Richer, M.J.; Pewe, L.L.; Hancox, L.S.; Hartwig, S.M.; Varga, S.M.; Harty, J.T. Inflammatory IL-15 is required for optimal memory T cell responses. J. Clin. Investig. 2015, 125, 3477-3490. [CrossRef]

52. Mishra, A.; La Perle, K.M.D.; Sullivan, L.; Sams, G.H.; Curphey, D.P.; McConnell, K.; Qi, J.; Wong, H.K.; Kulp, S.K.; Fernandez, S.; et al. Increased Expression Of IL-15 Promotes Cutaneous T-Cell Lymphomagenesis Via The Upregulation Of Histone Deacetylases: Evidence For Successful Preclinical Targeting. Blood 2013, 122, 1826. [CrossRef]

53. Yamanaka, K.; Clark, R.; Rich, B.; Dowgiert, R.; Hirahara, K.; Hurwitz, D.; Shibata, M.; Mirchandani, N.; Jones, D.A.; Goddard, D.S.; et al. Skin-derived interleukin-7 contributes to the proliferation of lymphocytes in cutaneous T-cell lymphoma. Blood 2006, 107, 2440-2445. [CrossRef]

54. Yeon, S.M.; Halim, L.; Chandele, A.; Perry, C.J.; Kim, S.H.; Kim, S.U.; Byun, Y.; Yuk, S.H.; Kaech, S.M.; Jung, Y.W. IL-7 plays a critical role for the homeostasis of allergen-specific memory CD4 T cells in the lung and airways. Sci. Rep. 2017, 7, 11155. [CrossRef] 
55. Richmond, J.M.; Strassner, J.P.; Zapata, L., Jr.; Garg, M.; Riding, R.L.; Refat, M.A.; Fan, X.; Azzolino, V.; Tovar-Garza, A.; Tsurushita, N.; et al. Antibody blockade of IL-15 signaling has the potential to durably reverse vitiligo. Sci. Transl. Med. 2018, 10, eaam7710. [CrossRef]

56. Zhou, M.; Guo, C.; Li, X.; Huang, Y.; Li, M.; Zhang, T.; Zhao, S.; Wang, S.; Zhang, H.; Yang, N. JAK/STAT signaling controls the fate of $\mathrm{CD} 8\left(^{+}\right) \mathrm{CD} 103\left({ }^{+}\right)$tissue-resident memory T cell in lupus nephritis. J. Autoimmun. 2020, 109, 102424. [CrossRef]

57. Azzolino, V.; Zapata, L., Jr.; Garg, M.; Gjoni, M.; Riding, R.L.; Strassner, J.P.; Richmond, J.M.; Harris, J.E. Jak Inhibitors Reverse Vitiligo in Mice but Do Not Deplete Skin Resident Memory T Cells. J. Investig. Dermatol. 2021, 141, 182-184.e181. [CrossRef]

58. Fantin, V.R.; Loboda, A.; Paweletz, C.P.; Hendrickson, R.C.; Pierce, J.W.; Roth, J.A.; Li, L.; Gooden, F.; Korenchuk, S.; Hou, X.S.; et al. Constitutive activation of signal transducers and activators of transcription predicts vorinostat resistance in cutaneous T-cell lymphoma. Cancer Res. 2008, 68, 3785-3794. [CrossRef]

59. Netchiporouk, E.; Litvinov, I.V.; Moreau, L.; Gilbert, M.; Sasseville, D.; Duvic, M. Deregulation in STAT signaling is important for cutaneous T-cell lymphoma (CTCL) pathogenesis and cancer progression. Cell Cycle 2014, 13, 3331-3335. [CrossRef]

60. Karagianni, F.; Piperi, C.; Mpakou, V.; Spathis, A.; Foukas, P.G.; Dalamaga, M.; Pappa, V.; Papadavid, E. Ruxolitinib with resminostat exert synergistic antitumor effects in Cutaneous T-cell Lymphoma. PLoS ONE 2021, 16, e0248298. [CrossRef]

61. Yumeen, S.; Mirza, F.N.; Lewis, J.M.; King, A.L.O.; Kim, S.R.; Carlson, K.R.; Umlauf, S.R.; Surovtseva, Y.V.; Foss, F.M.; Girardi, M. JAK inhibition synergistically potentiates BCL2, BET, HDAC, and proteasome inhibition in advanced CTCL. Blood Adv. 2020, 4, 2213-2226. [CrossRef]

62. Paul, M.S.; Ohashi, P.S. The Roles of CD8 $\left(^{+}\right)$T Cell Subsets in Antitumor Immunity. Trends Cell Biol. 2020, 30, 695-704. [CrossRef]

63. Natarajan, V.T.; Ganju, P.; Singh, A.; Vijayan, V.; Kirty, K.; Yadav, S.; Puntambekar, S.; Bajaj, S.; Dani, P.P.; Kar, H.K.; et al. IFN-gamma signaling maintains skin pigmentation homeostasis through regulation of melanosome maturation. Proc. Natl. Acad. Sci. USA 2014, 111, 2301-2306. [CrossRef]

64. Koguchi-Yoshioka, H.; Watanabe, R.; Matsumura, Y.; Okiyama, N.; Ishitsuka, Y.; Nakamura, Y.; Fujisawa, Y.; Fujimoto, M. The Possible Linkage of Granzyme B-Producing Skin T Cells with the Disease Prognosis of Alopecia Areata. J. Investig. Dermatol. 2021, 141, 427-429.e10. [CrossRef]

65. Vo, S.; Watanabe, R.; Koguchi-Yoshioka, H.; Matsumura, Y.; Ishitsuka, Y.; Nakamura, Y.; Okiyama, N.; Fujisawa, Y.; Fujimoto, M. CD8 resident memory T cells with interleukin 17A-producing potential are accumulated in disease-naive nonlesional sites of psoriasis possibly in correlation with disease duration. Br. J. Dermatol. 2019, 181, 410-412. [CrossRef]

66. Matos, T.R.; O’Malley, J.T.; Lowry, E.L.; Hamm, D.; Kirsch, I.R.; Robins, H.S.; Kupper, T.S.; Krueger, J.G.; Clark, R.A. Clinically resolved psoriatic lesions contain psoriasis-specific IL-17-producing alpha beta T cell clones. J. Clin. Investig. 2017, 127, 4031-4041 [CrossRef]

67. Nizard, M.; Roussel, H.; Diniz, M.O.; Karaki, S.; Tran, T.; Voron, T.; Dransart, E.; Sandoval, F.; Riquet, M.; Rance, B.; et al. Induction of resident memory $\mathrm{T}$ cells enhances the efficacy of cancer vaccine. Nat. Commun. 2017, 8, 15221. [CrossRef]

68. Malik, B.T.; Byrne, K.T.; Vella, J.L.; Zhang, P.; Shabaneh, T.B.; Steinberg, S.M.; Molodtsov, A.K.; Bowers, J.S.; Angeles, C.V.; Paulos, C.M.; et al. Resident memory $\mathrm{T}$ cells in the skin mediate durable immunity to melanoma. Sci. Immunol. 2017, 2, eaam6346. [CrossRef]

69. Murray, T.; Fuertes Marraco, S.A.; Baumgaertner, P.; Bordry, N.; Cagnon, L.; Donda, A.; Romero, P.; Verdeil, G.; Speiser, D.E. Very Late Antigen-1 Marks Functional Tumor-Resident CD8 T Cells and Correlates with Survival of Melanoma Patients. Front. Immunol. 2016, 7, 573. [CrossRef]

70. Clarke, J.; Panwar, B.; Madrigal, A.; Singh, D.; Gujar, R.; Wood, O.; Chee, S.J.; Eschweiler, S.; King, E.V.; Awad, A.S.; et al. Single-cell transcriptomic analysis of tissue-resident memory T cells in human lung cancer. J. Exp. Med. 2019, 216, 2128-2149. [CrossRef]

71. Lin, R.; Zhang, H.; Yuan, Y.; He, Q.; Zhou, J.; Li, S.; Sun, Y.; Li, D.Y.; Qiu, H.B.; Wang, W.; et al. Fatty Acid Oxidation Controls CD8 $\left(^{+}\right)$Tissue-Resident Memory T-cell Survival in Gastric Adenocarcinoma. Cancer Immunol. Res. 2020, 8, 479-492. [CrossRef]

72. Han, L.; Gao, Q.L.; Zhou, X.M.; Shi, C.; Chen, G.Y.; Song, Y.P.; Yao, Y.J.; Zhao, Y.M.; Wen, X.Y.; Liu, S.L.; et al. Characterization of CD103 $\left(^{+}\right) \mathrm{CD}^{(+}\left(^{+}\right.$tissue-resident T cells in esophageal squamous cell carcinoma: May be tumor reactive and resurrected by anti-PD-1 blockade. Cancer Immunol. Immunother. 2020, 69, 1493-1504. [CrossRef]

73. Savas, P.; Virassamy, B.; Ye, C.; Salim, A.; Mintoff, C.P.; Caramia, F.; Salgado, R.; Byrne, D.J.; Teo, Z.L.; Dushyanthen, S.; et al. Single-cell profiling of breast cancer T cells reveals a tissue-resident memory subset associated with improved prognosis. Nat. Med. 2018, 24, 986-993. [CrossRef]

74. Wang, Z.Q.; Milne, K.; Derocher, H.; Webb, J.R.; Nelson, B.H.; Watson, P.H. CD103 and Intratumoral Immune Response in Breast Cancer. Clin. Cancer Res. 2016, 22, 6290-6297. [CrossRef]

75. Wang, B.; Wu, S.; Zeng, H.; Liu, Z.; Dong, W.; He, W.; Chen, X.; Dong, X.; Zheng, L.; Lin, T.; et al. CD103 ${ }^{+}$Tumor Infiltrating Lymphocytes Predict a Favorable Prognosis in Urothelial Cell Carcinoma of the Bladder. J. Urol. 2015, 194, 556-562. [CrossRef]

76. Ganesan, A.P.; Clarke, J.; Wood, O.; Garrido-Martin, E.M.; Chee, S.J.; Mellows, T.; Samaniego-Castruita, D.; Singh, D.; Seumois, G.; Alzetani, A.; et al. Tissue-resident memory features are linked to the magnitude of cytotoxic T cell responses in human lung cancer. Nat. Immunol. 2017, 18, 940-950. [CrossRef]

77. Schenkel, J.M.; Fraser, K.A.; Vezys, V.; Masopust, D. Sensing and alarm function of resident memory CD8 $\left(^{+}\right)$T cells. Nat. Immunol. 2013, 14, 509-513. [CrossRef] 
78. McMaster, S.R.; Wilson, J.J.; Wang, H.; Kohlmeier, J.E. Airway-Resident Memory CD8 T Cells Provide Antigen-Specific Protection against Respiratory Virus Challenge through Rapid IFN-gamma Production. J. Immunol. 2015, 195, 203-209. [CrossRef]

79. Glasner, A.; Levi, A.; Enk, J.; Isaacson, B.; Viukov, S.; Orlanski, S.; Scope, A.; Neuman, T.; Enk, C.D.; Hanna, J.H.; et al. NKp46 Receptor-Mediated Interferon-gamma Production by Natural Killer Cells Increases Fibronectin 1 to Alter Tumor Architecture and Control Metastasis. Immunity 2018, 48, 107-119.e104. [CrossRef]

80. Collins, N.; Jiang, X.; Zaid, A.; Macleod, B.L.; Li, J.; Park, C.O.; Haque, A.; Bedoui, S.; Heath, W.R.; Mueller, S.N.; et al. Skin CD4( ${ }^{+}$) memory $\mathrm{T}$ cells exhibit combined cluster-mediated retention and equilibration with the circulation. Nat. Commun. 2016, 7, 11514. [CrossRef]

81. Klicznik, M.M.; Morawski, P.A.; Hollbacher, B.; Varkhande, S.R.; Motley, S.J.; Kuri-Cervantes, L.; Goodwin, E.; Rosenblum, M.D.; Long, S.A.; Brachtl, G.; et al. Human CD4 $\left({ }^{+}\right) \mathrm{CD} 103\left({ }^{+}\right)$cutaneous resident memory T cells are found in the circulation of healthy individuals. Sci. Immunol. 2019, 4, eaav8995. [CrossRef]

82. Turner, D.L.; Goldklang, M.; Cvetkovski, F.; Paik, D.; Trischler, J.; Barahona, J.; Cao, M.; Dave, R.; Tanna, N.; D’Armiento, J.M.; et al. Biased Generation and In Situ Activation of Lung Tissue-Resident Memory CD4 T Cells in the Pathogenesis of Allergic Asthma. J. Immunol. 2018, 200, 1561-1569. [CrossRef] [PubMed]

83. Vukmanovic-Stejic, M.; Sandhu, D.; Seidel, J.A.; Patel, N.; Sobande, T.O.; Agius, E.; Jackson, S.E.; Fuentes-Duculan, J.; SuarezFarinas, M.; Mabbott, N.A.; et al. The Characterization of Varicella Zoster Virus-Specific T Cells in Skin and Blood during Aging. J. Investig. Dermatol. 2015, 135, 1752-1762. [CrossRef] [PubMed]

84. Iijima, N.; Iwasaki, A. T cell memory. A local macrophage chemokine network sustains protective tissue-resident memory CD4 T cells. Science 2014, 346, 93-98. [CrossRef]

85. Ogongo, P.; Tezera, L.B.; Ardain, A.; Nhamoyebonde, S.; Ramsuran, D.; Singh, A.; Ng'oepe, A.; Karim, F.; Naidoo, T.; Khan, K.; et al. Tissue-resident-like CD4 ${ }^{+} \mathrm{T}$ cells secreting IL-17 control Mycobacterium tuberculosis in the human lung. J. Clin. Investig. 2021, 131, e142014. [CrossRef]

86. Hsi, A.C.; Lee, S.J.; Rosman, I.S.; Carson, K.R.; Kelley, A.; Viele, V.; Pang, X.; Musiek, A.; Schaffer, A. Expression of helper T cell master regulators in inflammatory dermatoses and primary cutaneous T-cell lymphomas: Diagnostic implications. J. Am. Acad. Dermatol. 2015, 72, 159-167. [CrossRef]

87. Vermeer, M.H.; van Doorn, R.; Dukers, D.; Bekkenk, M.W.; Meijer, C.J.; Willemze, R. CD8 ${ }^{+}$T cells in cutaneous T-cell lymphoma: Expression of cytotoxic proteins, Fas Ligand, and killing inhibitory receptors and their relationship with clinical behavior. J. Clin. Oncol. 2001, 19, 4322-4329. [CrossRef]

88. Jones, D.; Dang, N.H.; Duvic, M.; Washington, L.T.; Huh, Y.O. Absence of CD26 expression is a useful marker for diagnosis of T-cell lymphoma in peripheral blood. Am. J. Clin. Pathol. 2001, 115, 885-892. [CrossRef]

89. Borcherding, N.; Voigt, A.P.; Liu, V.; Link, B.K.; Zhang, W.; Jabbari, A. Single-Cell Profiling of Cutaneous T-Cell Lymphoma Reveals Underlying Heterogeneity Associated with Disease Progression. Clin. Cancer Res. 2019, 25, 2996-3005. [CrossRef] [PubMed]

90. Ormsby, A.; Bergfeld, W.F.; Tubbs, R.R.; Hsi, E.D. Evaluation of a new paraffin-reactive CD7 T-cell deletion marker and a polymerase chain reaction-based T-cell receptor gene rearrangement assay: Implications for diagnosis of mycosis fungoides in community clinical practice. J. Am. Acad. Dermatol. 2001, 45, 405-413. [CrossRef]

91. Vonderheid, E.C.; Bigler, R.D.; Kotecha, A.; Boselli, C.M.; Lessin, S.R.; Bernengo, M.G.; Polansky, M. Variable CD7 expression on T cells in the leukemic phase of cutaneous T cell lymphoma (Sezary syndrome). J. Investig. Dermatol. 2001, 117, 654-662. [CrossRef] [PubMed]

92. Raman, C. CD5, an important regulator of lymphocyte selection and immune tolerance. Immunol. Res. 2002, 26, 255-263. [CrossRef]

93. Matson, C.A.; Choi, S.; Livak, F.; Zhao, B.; Mitra, A.; Love, P.E.; Singh, N.J. CD5 dynamically calibrates basal NF-kappaB signaling in T cells during thymic development and peripheral activation. Proc. Natl. Acad. Sci. USA 2020, 117, 14342-14353. [CrossRef]

94. Hristov, A.C.; Tejasvi, T.; Wilcox, R.A. Cutaneous T-cell lymphomas: 2021 update on diagnosis, risk-stratification, and management. Am. J. Hematol. 2021, 96, 1313-1328. [CrossRef]

95. Sokolowska-Wojdylo, M.; Wenzel, J.; Gaffal, E.; Steitz, J.; Roszkiewicz, J.; Bieber, T.; Tuting, T. Absence of CD26 expression on skin-homing CLA ${ }^{+} \mathrm{CD}^{+} \mathrm{T}$ lymphocytes in peripheral blood is a highly sensitive marker for early diagnosis and therapeutic monitoring of patients with Sezary syndrome. Clin. Exp. Dermatol. 2005, 30, 702-706. [CrossRef]

96. Scala, E.; Russo, G.; Cadoni, S.; Narducci, M.G.; Girardelli, C.R.; De Pita, O.; Puddu, P. Skewed expression of activation, differentiation and homing-related antigens in circulating cells from patients with cutaneous T cell lymphoma associated with CD7- T helper lymphocytes expansion. J. Investig. Dermatol. 1999, 113, 622-627. [CrossRef] [PubMed]

97. Rindler, K.; Bauer, W.M.; Jonak, C.; Wielscher, M.; Shaw, L.E.; Rojahn, T.B.; Thaler, F.M.; Porkert, S.; Simonitsch-Klupp, I.; Weninger, W.; et al. Single-Cell RNA Sequencing Reveals Tissue Compartment-Specific Plasticity of Mycosis Fungoides Tumor Cells. Front. Immunol. 2021, 12, 666935. [CrossRef]

98. Buus, T.B.; Willerslev-Olsen, A.; Fredholm, S.; Blumel, E.; Nastasi, C.; Gluud, M.; Hu, T.; Lindahl, L.M.; Iversen, L.; Fogh, H.; et al. Single-cell heterogeneity in Sezary syndrome. Blood Adv. 2018, 2, 2115-2126. [CrossRef] [PubMed]

99. Zhang, Y.; Wang, Y.; Yu, R.; Huang, Y.; Su, M.; Xiao, C.; Martinka, M.; Dutz, J.P.; Zhang, X.; Zheng, Z.; et al. Molecular markers of early-stage mycosis fungoides. J. Investig. Dermatol. 2012, 132, 1698-1706. [CrossRef] [PubMed] 
100. Gaydosik, A.M.; Tabib, T.; Geskin, L.J.; Bayan, C.A.; Conway, J.F.; Lafyatis, R.; Fuschiotti, P. Single-Cell Lymphocyte Heterogeneity in Advanced Cutaneous T-cell Lymphoma Skin Tumors. Clin. Cancer Res. 2019, 25, 4443-4454. [CrossRef]

101. Miyagawa, F.; Iioka, H.; Fukumoto, T.; Kobayashi, N.; Asada, H. A case of $C D 8\left(^{+}\right)$primary cutaneous peripheral T-cell lymphoma arising from tissue-resident memory T cells in the skin. Br. J. Dermatol. 2015, 173, 612-614. [CrossRef]

102. Campbell, J.J.; Clark, R.A.; Watanabe, R.; Kupper, T.S. Sezary syndrome and mycosis fungoides arise from distinct T-cell subsets: A biologic rationale for their distinct clinical behaviors. Blood 2010, 116, 767-771. [CrossRef] [PubMed]

103. Sallusto, F.; Lenig, D.; Forster, R.; Lipp, M.; Lanzavecchia, A. Two subsets of memory T lymphocytes with distinct homing potentials and effector functions. Nature 1999, 401, 708-712. [CrossRef] [PubMed]

104. Gehad, A.; Teague, J.E.; Matos, T.R.; Huang, V.; Yang, C.; Watanabe, R.; O’Malley, J.T.; Trimble, C.L.; Kupper, T.S.; Clark, R.A. A primary role for human central memory cells in tissue immunosurveillance. Blood Adv. 2018, 2, 292-298. [CrossRef] [PubMed]

105. Miyagaki, T.; Sugaya, M.; Suga, H.; Kamata, M.; Ohmatsu, H.; Fujita, H.; Asano, Y.; Tada, Y.; Kadono, T.; Sato, S. IL-22, but not IL-17, dominant environment in cutaneous T-cell lymphoma. Clin. Cancer Res. 2011, 17, 7529-7538. [CrossRef]

106. Guenova, E.; Watanabe, R.; Teague, J.E.; Desimone, J.A.; Jiang, Y.; Dowlatshahi, M.; Schlapbach, C.; Schaekel, K.; Rook, A.H.; Tawa, M.; et al. TH2 cytokines from malignant cells suppress TH1 responses and enforce a global TH2 bias in leukemic cutaneous T-cell lymphoma. Clin. Cancer Res. 2013, 19, 3755-3763. [CrossRef]

107. Dobbeling, U.; Dummer, R.; Laine, E.; Potoczna, N.; Qin, J.Z.; Burg, G. Interleukin-15 is an autocrine/paracrine viability factor for cutaneous T-cell lymphoma cells. Blood 1998, 92, 252-258. [CrossRef]

108. Mishra, A.; La Perle, K.; Kwiatkowski, S.; Sullivan, L.A.; Sams, G.H.; Johns, J.; Curphey, D.P.; Wen, J.; McConnell, K.; Qi, J.; et al. Mechanism, Consequences, and Therapeutic Targeting of Abnormal IL15 Signaling in Cutaneous T-cell Lymphoma. Cancer Discov. 2016, 6, 986-1005. [CrossRef]

109. Kok, L.; Masopust, D.; Schumacher, T.N. The precursors of $\mathrm{CD} 8\left(^{+}\right)$tissue resident memory T cells: From lymphoid organs to infected tissues. Nat. Rev. Immunol. 2021. [CrossRef]

110. Herndler-Brandstetter, D.; Ishigame, H.; Shinnakasu, R.; Plajer, V.; Stecher, C.; Zhao, J.; Lietzenmayer, M.; Kroehling, L.; Takumi, A.; Kometani, K.; et al. KLRG1 $\left(^{+}\right)$Effector CD8 $\left({ }^{+}\right)$T Cells Lose KLRG1, Differentiate into All Memory T Cell Lineages, and Convey Enhanced Protective Immunity. Immunity 2018, 48, 716-729.e718. [CrossRef]

111. Mackay, L.K.; Rahimpour, A.; Ma, J.Z.; Collins, N.; Stock, A.T.; Hafon, M.L.; Vega-Ramos, J.; Lauzurica, P.; Mueller, S.N.; Stefanovic, T.; et al. The developmental pathway for $\mathrm{CD} 103\left(^{+}\right) \mathrm{CD}^{+}$tissue-resident memory T cells of skin. Nat. Immunol. 2013, 14, 1294-1301. [CrossRef]

112. Hirai, T.; Zenke, Y.; Yang, Y.; Bartholin, L.; Beura, L.K.; Masopust, D.; Kaplan, D.H. Keratinocyte-Mediated Activation of the Cytokine TGF-beta Maintains Skin Recirculating Memory CD8 $\left(^{+}\right)$T Cells. Immunity 2019, 50, 1249-1261.e1245. [CrossRef]

113. Mohammed, J.; Beura, L.K.; Bobr, A.; Astry, B.; Chicoine, B.; Kashem, S.W.; Welty, N.E.; Igyarto, B.Z.; Wijeyesinghe, S.; Thompson, E.A.; et al. Stromal cells control the epithelial residence of DCs and memory T cells by regulated activation of TGF-beta. Nat. Immunol. 2016, 17, 414-421. [CrossRef] [PubMed]

114. McGill, J.; Van Rooijen, N.; Legge, K.L. IL-15 trans-presentation by pulmonary dendritic cells promotes effector CD8 T cell survival during influenza virus infection. J. Exp. Med. 2010, 207, 521-534. [CrossRef]

115. Kok, L.; Dijkgraaf, F.E.; Urbanus, J.; Bresser, K.; Vredevoogd, D.W.; Cardoso, R.F.; Perie, L.; Beltman, J.B.; Schumacher, T.N. A committed tissue-resident memory $\mathrm{T}$ cell precursor within the circulating CD8 ${ }^{+}$effector T cell pool. J. Exp. Med. 2020, 217, e20191711. [CrossRef] [PubMed]

116. Borges da Silva, H.; Peng, C.; Wang, H.; Wanhainen, K.M.; Ma, C.; Lopez, S.; Khoruts, A.; Zhang, N.; Jameson, S.C. Sensing of ATP via the Purinergic Receptor P2RX7 Promotes CD8 $\left(^{+}\right)$Trm Cell Generation by Enhancing Their Sensitivity to the Cytokine TGF-beta. Immunity 2020, 53, 158-171.e156. [CrossRef]

117. Wood, G.S.; Edinger, A.; Hoppe, R.T.; Warnke, R.A. Mycosis fungoides skin lesions contain CD8 ${ }^{+}$tumor-infiltrating lymphocytes expressing an activated, MHC-restricted cytotoxic T-lymphocyte phenotype. J. Cutan. Pathol. 1994, 21, 151-156. [CrossRef] [PubMed]

118. Kume, M.; Kiyohara, E.; Matsumura, Y.; Koguchi-Yoshioka, H.; Tanemura, A.; Hanaoka, Y.; Taminato, M.; Tashima, H.; Tomita, K.; Kubo, T.; et al. Ganglioside GD3 May Suppress the Functional Activities of Benign Skin T Cells in Cutaneous T-Cell Lymphoma. Front. Immunol. 2021, 12, 651048. [CrossRef]

119. Johnson, V.E.; Vonderheid, E.C.; Hess, A.D.; Eischen, C.M.; McGirt, L.Y. Genetic markers associated with progression in early mycosis fungoides. J. Eur. Acad. Dermatol. Venereol. 2014, 28, 1431-1435. [CrossRef]

120. De Monte, L.; Reni, M.; Tassi, E.; Clavenna, D.; Papa, I.; Recalde, H.; Braga, M.; Di Carlo, V.; Doglioni, C.; Protti, M.P. Intratumor T helper type 2 cell infiltrate correlates with cancer-associated fibroblast thymic stromal lymphopoietin production and reduced survival in pancreatic cancer. J. Exp. Med. 2011, 208, 469-478. [CrossRef]

121. Suzuki, A.; Leland, P.; Joshi, B.H.; Puri, R.K. Targeting of IL-4 and IL-13 receptors for cancer therapy. Cytokine 2015, 75, 79-88. [CrossRef]

122. Pedroza-Gonzalez, A.; Xu, K.; Wu, T.C.; Aspord, C.; Tindle, S.; Marches, F.; Gallegos, M.; Burton, E.C.; Savino, D.; Hori, T.; et al. Thymic stromal lymphopoietin fosters human breast tumor growth by promoting type 2 inflammation. J. Exp. Med. 2011, 208, 479-490. [CrossRef] 
123. Miyagaki, T.; Sugaya, M.; Suga, H.; Ohmatsu, H.; Fujita, H.; Asano, Y.; Tada, Y.; Kadono, T.; Sato, S. Increased CCL18 expression in patients with cutaneous T-cell lymphoma: Association with disease severity and prognosis. J. Eur. Acad. Dermatol. Venereol. 2013, 27, e60-e67. [CrossRef] [PubMed]

124. Gunther, C.; Zimmermann, N.; Berndt, N.; Grosser, M.; Stein, A.; Koch, A.; Meurer, M. Up-regulation of the chemokine CCL18 by macrophages is a potential immunomodulatory pathway in cutaneous T-cell lymphoma. Am. J. Pathol. 2011, 179, 1434-1442. [CrossRef]

125. Sahai, E.; Astsaturov, I.; Cukierman, E.; DeNardo, D.G.; Egeblad, M.; Evans, R.M.; Fearon, D.; Greten, F.R.; Hingorani, S.R.; Hunter, T.; et al. A framework for advancing our understanding of cancer-associated fibroblasts. Nat. Rev. Cancer 2020, 20, 174-186. [CrossRef] [PubMed]

126. Lim, B.; Woodward, W.A.; Wang, X.; Reuben, J.M.; Ueno, N.T. Inflammatory breast cancer biology: The tumour microenvironment is key. Nat. Rev. Cancer 2018, 18, 485-499. [CrossRef] [PubMed]

127. Tanita, K.; Fujimura, T.; Sato, Y.; Lyu, C.; Kambayashi, Y.; Ogata, D.; Fukushima, S.; Miyashita, A.; Nakajima, H.; Nakamura, M.; et al. Bexarotene Reduces Production of CCL22 From Tumor-Associated Macrophages in Cutaneous T-Cell Lymphoma. Front. Oncol. 2019, 9, 907. [CrossRef]

128. Wu, X.; Singh, R.; Hsu, D.K.; Zhou, Y.; Yu, S.; Han, D.; Shi, Z.; Huynh, M.; Campbell, J.J.; Hwang, S.T. A Small Molecule CCR2 Antagonist Depletes Tumor Macrophages and Synergizes with Anti-PD-1 in a Murine Model of Cutaneous T-Cell Lymphoma (CTCL). J. Investig. Dermatol. 2020, 140, 1390-1400.e1394. [CrossRef]

129. Miyagaki, T.; Sugaya, M.; Fujita, H.; Ohmatsu, H.; Kakinuma, T.; Kadono, T.; Tamaki, K.; Sato, S. Eotaxins and CCR3 interaction regulates the Th2 environment of cutaneous T-cell lymphoma. J. Investig. Dermatol. 2010, 130, 2304-2311. [CrossRef]

130. Miyagaki, T.; Sugaya, M.; Suga, H.; Morimura, S.; Ohmatsu, H.; Fujita, H.; Asano, Y.; Tada, Y.; Kadono, T.; Sato, S. Low herpesvirus entry mediator (HVEM) expression on dermal fibroblasts contributes to a Th2-dominant microenvironment in advanced cutaneous T-cell lymphoma. J. Investig. Dermatol. 2012, 132, 1280-1289. [CrossRef]

131. Aronovich, A.; Moyal, L.; Gorovitz, B.; Amitay-Laish, I.; Naveh, H.P.; Forer, Y.; Maron, L.; Knaneh, J.; Ad-El, D.; Yaacobi, D.; et al. Cancer-Associated Fibroblasts in Mycosis Fungoides Promote Tumor Cell Migration and Drug Resistance through CXCL12/CXCR4. J. Investig. Dermatol. 2021, 141, 619-627.e612. [CrossRef]

132. Mehdi, S.J.; Moerman-Herzog, A.; Wong, H.K. Normal and cancer fibroblasts differentially regulate TWIST1, TOX and cytokine gene expression in cutaneous T-cell lymphoma. BMC Cancer 2021, 21, 492. [CrossRef] [PubMed]

133. Mantovani, A.; Sozzani, S.; Locati, M.; Allavena, P.; Sica, A. Macrophage polarization: Tumor-associated macrophages as a paradigm for polarized M2 mononuclear phagocytes. Trends Immunol. 2002, 23, 549-555. [CrossRef]

134. Takahashi, N.; Sugaya, M.; Suga, H.; Oka, T.; Kawaguchi, M.; Miyagaki, T.; Fujita, H.; Sato, S. Thymic Stromal Chemokine TSLP Acts through Th2 Cytokine Production to Induce Cutaneous T-cell Lymphoma. Cancer Res. 2016, 76, 6241-6252. [CrossRef] [PubMed]

135. Notohamiprodjo, M.; Segerer, S.; Huss, R.; Hildebrandt, B.; Soler, D.; Djafarzadeh, R.; Buck, W.; Nelson, P.J.; von Luettichau, I. CCR10 is expressed in cutaneous T-cell lymphoma. Int. J. Cancer 2005, 115, 641-647. [CrossRef] [PubMed]

136. Ferenczi, K.; Fuhlbrigge, R.C.; Pinkus, J.; Pinkus, G.S.; Kupper, T.S. Increased CCR4 expression in cutaneous T cell lymphoma. J. Investig. Dermatol. 2002, 119, 1405-1410. [CrossRef] [PubMed] 